\title{
Clinical experimentation with aerosol antibiotics: current and future methods of administration [Corrigendum]
}

\author{
Zarogoulidis P, Kioumis I, Porpodis K, Spyratos D, \\ Tsakiridis K, Huang H, Li Q, Turner JF, Browning R, \\ Hohenforst-Schmidt W, Zarogoulidis K. Drug Des Devel \\ Ther. 2013;7:1115-1134.
}

Throughout the paper Microsprayer should have been cited as MicroSprayer ${ }^{\circledR}$ Aerosolizer (Penn-Century, Inc., Wyndmoor, PA, USA).

On page 1127 and 1128 the paragraph on Azithromycin should not have been included in the paper.

\section{Publish your work in this journal}

Drug Design, Development and Therapy is an international, peerreviewed open-access journal that spans the spectrum of drug design and development through to clinical applications. Clinical outcomes, patient safety, and programs for the development and effective, safe, and sustained use of medicines are a feature of the journal, which has also been accepted for indexing on PubMed Central. The manuscript management system is completely online and includes a very quick and fair peer-review system, which is all easy to use. Visit http://www.dovepress.com/testimonials.php to read real quotes from published authors submit your manuscript | www.dovepress.com

Dovepress

http://dx.doi.org// 0.2147/DDDT.S58090 